\title{
Membangun Pemahaman Multikultural dan Multiagama Guna Menangkal Radikalisme di Aceh Singkil
}

\author{
Deny Setiawan dan Bahrul Khoir Amal \\ Universitas Negeri Medan (UNIMED) \\ bukharyahmedal@gmail.com
}

\begin{abstract}
Multicultural education is an educational reform movement. This process is mainly aimed to change the structure of educational institutions. At this stage, students who are members of diverse racial, ethnic, and cultural groups will have an equal chance to achieve better academic values in school. Multi-religion is a situation where there is an existence of some religions in a certain area in which exists in a multi-cultural region. Conflicts which might emerge in Singkil of Aceh are caused by some factors. Among others: lack of the understanding through the existence of multicultural, lack of solidarity among the religious people (multireligion), and the people from the outside of Aceh Singkil who wants to destroy the stability in this area. Economic disparities and live in poverty for many years is also as another factor rising this conflict, even if it is not the dominant factor.
\end{abstract}

\begin{abstract}
Abstrak
Multi-budaya adalah salah satu pergerakan reformasi pendidikan. dan proses yang tujuannya untuk mengubah struktur pendidikan agar siswa yang berasal dari suku, ras dan kelompok budaya yang berbeda bisa memiliki kesempatan yang sama untuk memperoleh pendidikan di sekolah. Multi-agama adalah suatu keadaan di mana ada beberapa agama yang hidup dan berkembang di daerah tertentu yang keberadaannya tidak bisa ditolak.Konflik yang baru-baru ini terjadi di Aceh Singkil, yang sebenarnya ini bukan merupakan konflik yang pertama, disebabkan oleh beberapa faktor yaitu: 1. Kurangnya pemahaman tentang konsep multikultural yang ada dan hidup serta berkembang sejak lama di Aceh Singkil. 2. Kurangnya rasa solidaritas yang tinggi dalam beragama di tengah-tengah masyarakat yang juga multi agama, meskipun ada agama mayoritas di daerah tersebut. 3. Adanya usaha dari masyarakat pendatang ke Aceh Singkil yang ingin merusak stabilitas kehidupan di sana dengan tidak mematuhi aturan-aturan yang telah disepakati. 4. Kesenjangan ekonomi dan hidup dalam kemiskinan yang bertahun-tahun dialami masyarakat Aceh Singkil juga merupakan faktor terjadinya konflik tersebut, sekalipun faktor ini tidak dominan.
\end{abstract}

Keywords ;Multi-culture; multi-religion; radicalism; Aceh Singkil 


\section{A. Pendahuluan}

Praktek kekerasan yang mengatasnamakan agama, dari fundamentalisme, radikalisme, hingga terorisme, akhir-akhir ini semakin marak di tanah air. Kesatuan dan persatuan bangsa saat ini sedang diuji eksistensinya. Banyak factor yang menunjukkan adanya tanda-tanda perpecahan bangsa, dengan transparan mudah kita baca. Konflik di Ambon, Papua, maupun Poso, serta Aceh Singkil seperti api dalam sekam, sewaktu-waktu bisa meledak, walaupun berkali-kali bisa diredam. Peristiwa tersebut, bukan saja telah banyak merenggut korban jiwa, tetapi juga telah menghancurkan ratusan tempat ibadah (baik masjid maupun gereja).

Bila kita amati, agama seharusnya dapat menjadi pendorong bagi ummat manusia untuk selalu menegakkan perdamaian dan meningkatkan kesejahteraan bagi seluruh ummat di bumi ini. Namun, realitanya agama justru menjadi salah satu penyebab terjadinya kekerasanan dan kehancuran umat manusia. Oleh karena itu, diperlukan upaya-upaya preventif agar masalah pertentangan agama tidak akan terulang lagi di masa yang akan datang. Misalnya, dengan mengintensifkan forum-forum dialog antar ummat beragama dan aliran kepercayaan (dialog antar iman), membangun pemahaman keagamaan yang lebih pluralis dan inklusif, dan memberikan pendidikan tentang pluralisme dan toleransi beragama melalui sekolah (lembaga pendidikan).

Realita tersebut menunjukkan bahwa pendidikan agama baik di sekolah umum maupun sekolah agama lebih bercorak eksklusive, yaitu agama diajarkan dengan cara menafikan hak hidup agama lain, seakanakan hanya agamanya sendiri yang benar dan mempunyai hak hidup, sementara agama yang lain salah, tersesat dan terancam hak hidupnya, baik di kalangan mayoritas maupun minoritas. Seharusnya pendidikan agama dapat dijadikan sebagai wahana untuk mengembangkan moralitas universal yang ada dalam agama-agama sekaligus mengembangkan teologi inklusif dan pluralis. Berkaitan dengan hal ini, maka penting bagi institusi pendidikan dalam masyarakat yang multikultur untuk mengajarkan perdamaian dan resolusi konflik seperti yang ada dalam pendidikan multikultural.

Indonesia merupakan salah satu negara besar di dunia yang di dalamnya banyak terdapat suku-suku, budaya, kekhasan daerah bahkan juga agama atau kepercayaan yang dianut juga beragam. Da banya suku di Indonesia, di antaranya: Jawa, Padang, Batak, Melayu, dan lain-lain. 
Begitu juga agama yang ada di Indonesia, ada Islam, Kristen, Budha, Hindu dan Kristen Protestan. Di Indonesia juga banyak kita temukan berbagai macam aliran keagamaan. Keberagaman budaya dan agama ini seharusnya menjadi harta yang tak ternilai harganya dan bukan akhirnya menimbulkan berbagai macam konflik sosial, ras, budaya dan agama di Indonesia.

Pemerintah telah memetakan beberapa daerah yang rawan akan konflik SARA, salah satunya propinsi Aceh. Dan ternyata benar, konflik yang bernuansa SARA akhirnya terjadi di Aceh Singkil baru-baru ini. Konflik yang terus-menerus terjadi di Aceh Singkil telah membuat peneliti ingin mengetahui secara pasti apa sebenarnya penyebab utama terjadinya konflik tersebut. Di sinilah peneliti akhirnya berinisiatif untuk melakukan penelitian yang mendalam tentang akar penyebab terjadinya konflik tersebut.

Konflik yang terjadi ini, telah menginspirasi peneliti untuk melakukan penelitian lapangan di Aceh Singkil selama 3 bulan untuk melihat apa sebenarnya akar penyebab terjadinya konflik agama di Aceh Singkil. Artikel ini menjawab permasalahan apakah konflik di Aceh Singkil terjadi karena agama, budaya ataukah kemiskinan? metode wawancara dan tanya jawab kepada tokoh-tokoh masyarakat maupun masyarakat biasa untuk mengumpulkan data sebenarnya untuk mengetahui penyebab konflik tersebut.

\section{A. Makna Multikultur}

Umumnya, kultur diartikan sebatas pada budaya dan kebiasaan sekelompok orang pada daerah tertentu ${ }^{1}$. Secara etimologis, multikulturalisme dibentuk dari kata multi (banyak), kultur (budaya), dan isme (aliran/paham) $)^{2}$. Multikultur sebenarnya merupakan kata dasar yang mendapat awalan. Kata dasar itu adalah kultur yang berarti kebudayaan atau pemeliharaan, sedang awalannya adalah multi yang berarti banyak, ragam, atau aneka. Dengan demikian, multikultur berarti keragaman kebudayaan atau banyak pemeliharaan.

Multikulturalisme dapat dikatakan berkembang dari negara besar demokrasi yaitu Amerika Serikat. Amerika Serikat sebagai pentolan

\footnotetext{
1 Ainul Yaqin., Pendidikan Multikultural: Cross-Culttiral Understanding untuk Demokrasi dan Keadilan, (Yogjakarta: Pilar Media, 2005) h. 6

2 Tilaar, H.A.R, , Pendidikan Kebudayaan, dan Masyarakat Madani Indonesia: Strategi Reformasi Pendidikan Nastonal, (Bandung: Remaja Rossda-karya, 2000)
} 
demokrasi, masyarakatnya dapat hidup dengan subur dalam segregasi dan diskriminasi ras. Sejarah mencatat terjadinya perang saudara pada pertengahan abad ke-19 sebenarnya merupakan cikal-bakal lahirnya multikulturalisme di dunia. Abraham Lincoln sebagai pejuang demokrasi dengan politik abolisinya dapat menghapus perbudakan. Hasil perjuangannya menempatkan ras negro pada tempat yang layak di Amerika Serikat. Hal ini dapat dijadikan bukti bahwa ras dengan kultur minoritas dapat berbaur dengan ras dan kultur yang lebih kompleks, yang berarti menjadikan multikultur dapat bersinergi dalam ras dan kultur yang bervariatif.

Lalu bagaimana dengan Indonesia sendiri? Indonesia, tanah air kita memiliki karakteristik yang amat mengagumkan apabila dilihat dari aspek fisik, sosial, dan budaya. Dengan lebih dari 17.000 pulau besar dan kecil tersebar pada wilayah seluas lebih dari 5.000.000 kilometer persegi, dari kota Sabang di penghujung sebelah barat sampai kota Merauke di penghujung sebelah timur dan dari pulau Miangas di ujung utara sampai pulau Rote di ujung sebelah selatan. Luas geografis kepulauan Indonesia lebih luas dari Eropa Barat, dan hampir sebanding dengan Amerika Serikat dan Australia. Dengan jumlah penduduk sekitar 230 juta jiwa, Indonesia kini menduduki peringkat keempat negara paling padat di dunia. Indonesia memiliki warisan dan tantangan pluralisme budaya (cultural pluralism) secara lebih mencolok, sehingga dipandang sebagai "lokus klasik" bagi bentukan baru "masyarakat majemuk" (plural society). Fenomena masyarakat dan kompeks kebudayaannya yang masing-masing plural (jamak) dan sekaligus juga heterogen (aneka ragam) itu tergambar dalam prinsip bhinneka tunggal ika, yang berarti bercorak-ragam kehidupan dan penghidupan, tetapi terintegrasi dalam kesatuan.

Fakta realitas, jelas menggambarkan masyarakat Indonesia sebagai masyarakat multikultural. Sesuai dengan prinsip bhineka tunggal ika, maka sebenarnya pendidikan multikultural sebagai pendidikan alternatif patut dikembangkan dan dijadikan sebagai model pendidikan di Indonesia. Ada beberapa alasan mengenai hal tersebut. Pertama, realitas bahwa Indonesia adalah negara yang dihuni oleh berbagai suku, bangsa, etnis, agama, dengan bahasa yang beragam dan membawa budaya yang heterogen serta tradisi dan peradaban yang beraneka ragam. Kedua, pluralitas tersebut secara inheren sudah ada sejak bangsa Indonesia ini ada. Ketiga, masyarakat menentang pendidikan yang berorientasi bisnis, komersialisasi, dan kapitalis yang mengutamakan golongan atau orang 
tertentu. Keempat, masyarakat tidak menghendaki kekerasan dan kesewenang-wenangan pelaksanaan hak setiap orang. Kelima, pendidikan multikultur sebagai resistensi fanatisme yang mengarah pada berbagai jenis kekerasan, dan kesewenang-wenangan. Keenam, pendidikan multikultural memberikan harapan dalam rnengatasi berbagai gejolak masyarakat yang terjadi akhir-akhir ini. Ketujuh, pendidikan multikultur sarat dengan nilai-nilai kemanusiaan, sosial, kealaman, dan ke- Tuhanan.

Dari beberapa alasan di atas, nampaknya perlu dibangun paradigma pendidikan multikultural di Indonesia. Paradigma pendidikan multikultural dapat dikatakan bahwa sebenarnya paradigma yang telah muncul sampai saat ini adalah paradigma teosentrisme, kosmosentrisme, dan antroposenirisme. Suatu paradigma yang rnemandang segala sesuatu ada yang memiliki kekuatan yang paling menentukan segala sesuatunya, yaitu Tuhan. Tuhan diposisikan sedemikian sentralnya menjadi acuan seluruh perilaku manusia. Sebagai bukti ke maha kuasaannya Tuhan memberikan alam dan segala isinya untuk menjadikan manusia hidup dengan bergantung pada kemampuan kosmos. Atas ketergantungan tersebut manusia hendaknya memiliki kesadaran kosmosentrisme untuk memanfaatkan, mengembangkan, dan melestarikan seluruh tatanan bumi dengan arif dan bijaksana. Paham antroposentrisme yang mengakui ukuran kebaikan dan kebenaran itu terletak pada akal budi manusia. Untuk meraih kebaikan hidup, baik individu maupun sosial, manusia harus mengembangkan akal budinya. Menurut Khoironi, manusia harus siap dengan perubahan-perubahan yang terjadi pada setiap ruas kehidupannya, termasuk kebudayaan yang progresif ${ }^{3}$

Dengan totalitas ketiga paradigma tersebut diharapkan dapat menerbitkan manusia yang mampu menjalankan tugas hidup manusia yang saling bekerjasama sehingga mampu hidup (to make a living), mengembangkan kehidupan yang bermakna (to lead a meaningful life), dan untuk turut memuliakan kehidupan (to ennoble life).

\section{B. Makna Multiagama}

Agama adalah sebuah koleksi terorganisir dari kepercayaan, sistem budaya, dan pandangan dunia yang menghubungkan manusia dengan tatanan/perintah dari kehidupan. Banyak agama memiliki narasi, simbol, dan sejarah suci yang dimaksudkan untuk menjelaskan makna hidup dan / atau menjelaskan asal usul kehidupan dan sebagainya.

\footnotetext{
${ }^{3}$ Khoironi., Pendidikan Profetik, (Jogjakarta: Pustaka Pelajar, 2004)
} 
Multi agama adalah istilah khusus dalam kajian agama agama. Sebagai terminologi khusus istilah ini tidak dapat dimaknai sembarangan, misalnya disamakan dengan makna istilah toleransi, saling menghormati dan sebagainya. Sebagai satu paham )isme) yang membahas cara pandang terhdap agama agama yang ada, istilah pluralisme agama, telah menjadi pembahasan panjang di kalangan para ilmua dalam studi agama - agama.

\section{Pendidikan Multikultural untuk Multikulturalisme}

Pendidikan multikultural merupakan sebuah paradigma baru yang lahir pada akhir abad XX, yang memiliki visi, program, strategi dan metodologi pendidikan yang perlu untuk mempersiapkan generasi muda menghadapi masyarakat dunia global dan multikultural.

Menurut pakar pendidikan multicultural, Banks mendifiniskan pendidikan multikultural sebagai berikut:

"Multicultural education is a progressive approach for transforming education that hostically critique and address currents shortcomings, failings, discriminatory practices in education. It is grounded in deals of social justice, education equity, and a dedication to facilitating seducation experiences in which all students reach their full potensial as learners and as socially aware and active beings, locally, and globally". 4

Bagaimana mengimplementasikan konsep pendidikan multikultural ini dalam pendidikan praktis di sekolah? Terdapat 3 (tiga) komponen implementasi yang dapat dipergunakan sebagai strategi program pembelajaran, yaitu sebagai berikut: (1) Content oriented program, yang terdiri dari: a. mengembangkan materi pendidikan multikultural dalam semua disiplin ilmu, b. memadukan keberagaman pandangan dan cara pandang dalam kurikulum, c. mentransfer tujuan dalam konsep kurikulum baru; (2) Student oriented program, yang terdiri dari: a. melakukan penelitian terhadap model belajar berbagai kelompok murid, b. program menggunakan sekaligus dua atau lebih bahasa pengantar dalam sekolah, c. spesial program untuk murid-murid yang terkebelakang atau terpinggirkan secara sosio-ekonomi dalam masyarakat;

${ }^{4}$ Banks, J.A. An Introduction to multicultural education, (Boston: Allyn and Bacon, 1994). 
(3) Socially oriented program, yang terdiri dari: a. kontak antara kelompok-kelompok yang berbeda (ras, agama, dan sosio-ekonomi), b. program belajar bersama.

Dalam pendidikan multikultur selalu muncul kata kunci kultural, pluralitas dan pendidikan. Pemahaman terhadap pluralitas mencakup segala perbedaan dan keragaman, sedangkan kultur itu sendiri tidak dapat lepas dari empat terma penting yaitu aliran (agama), ras (golongan), suku (etnis), dan budaya. Dalam pendidikan multikultur berarti pengakuan atas empat terma penting tersebut untuk memprogramkan berlangsungnya pendidikan multikultur.

Pengakuan keempat terma penting tersebut menjadikan ciri khas pendidikan multikultur. Pendidikan yang berorientasi multikultur harus dapat memahami keberadaan masyarakat plural yang memiliki groupthink yang membutuhkan ikatan-ikatan keadaban (the bound of civility). The bound of civility berupa pergaulan antar kultur yang diikat dengan suatu civility (keadaban). Ikatan ini dibangun dari nilai-nilai universal manusia.

Nilai-nilai universal manusia tersebut perlu ditransfer kepada masyarakat agar menemukan tujuan kepemilikan dan kelanggengan. Kepemilikan nilai-nilai universal yang dapat melembaga pada masyarakat untuk mewujudkan budaya luhur yang sesuai dengan nilai keuniversalan manusia. Dengan demikian, nilai-nilai luhur dapat diwujudkan untuk menciptakan kehidupan masyarakat yang aman, tertib, berwibawa, dan bermartabat.

Untuk mentransfer nilai-nilai keuniversalan tersebut, masyarakat tetap meyakini dan mengakui bahwa transmitter nilai-nilai universal tersebut melalui proses pendidikan. Karena itu, segala perangkat yang mengacu pada pencapaian hasil tersebut diorientasikan pada tujuan utama pendidikan dengan kesiapan menghadapi masyarakat multikultur.

Berdasarkan paparan di atas, maka pendidikan multikultural pada era ini sudah selayaknya mengangkat multikulturalisme sebagai paham yang humanis, dan bila dikaji dari perjalanan pluralisme di Indonesia dapat diprioritaskan pada pembangunan: multikulturalisme sebagai politic of recognition, multikultur dalam etnic and cultural groups, multikulturalisme dalam karakteristik sosial.

Multikulturalisme sebagai sebuah paham (politic of recognition) menekankan pada kesenjangan dan kesetaraan budaya-budaya lokal tanpa mengabaikan hak-hak dan eksistensi budaya yang ada. Jadi beragam budaya harus dibangun seharmonis mungkin yang ada dalam satu wilayah tertentu 
Secara hakiki, dalam kata itu terkandung pengakuan martabat manusia yang hidup dalam komunitasnya dengan kebudayaan masingmasing yang unik. Pengakuan berarti penghargaan akan keberbedaan yang dimiliki oleh orang lain. Menurut seorang pakar pendidikan, Assegaf, menghargai perbedaan berarti siap untuk menerima kehadiran orang lain di tengah kehidupan kita secara kolektif, learning to live togather. Dengan demikian, setiap individu merasa dihargai sekaligus merasa bertanggung jawab untuk hidup bersama komunitasnya. Secara idealis, penghargaan dan pengakuan masing-masing individu tersebut akan terbangun komunitas yang harmonis. Pengakuan dan penerimaan atas keanekaan tersebut merupakan politic of recognition yang harus dijunjung tinggi. Secara politis, pengakuan tersebut bermuatan cukup strategis. Nilai strategis tersebut terdapat pada unsur penerimaan secara timbal balik. Berlangsungnya timbal balik tersebut menjadi jaminan berkembangnya antar kultur. Pengingkaran terhadap berkembangnya kultur masyarakat terhadap kebutuhan untuk diakui merupakan akar dari ketimpanganketimpangan dalam berbagai bidang kehidupan.

Sedangkan pakar pendidikan multicultural lainnya, Dewey, mengungkapkan masyarakat multikultur berasal dari dua kata yaitu masyarakat dan multikultur. Masyarakat merupakan satu kata yang mengandung banyak arti. Masyarakat ada dari proses berhimpun, saling mengasihi, serta kebersamaan dalam tujuan, kemaslahatan, dan keikhlasan untuk mencapai tujuan umumny. Masyarakat multikultur atau multibudaya berarti mereka yang telah mempelajari dan menggunakan kebudayaan secara cepat, efektif, jelas, serta ideal dalam interaksi dan komunikasi dengan orang lain. Definisi ini jelas merujuk kepada masyarakat yang memiliki budaya sekaligus melaksanakan budaya yang dijunjung tinggi dalam masyarakat yang bersangkutan. Melaksanakan ritual budaya yang dijunjung tinggi tersebut digunakan untuk berinteraksi dan berkomunikasi dengan budaya lain. Interaksi dan komunikasi tersebut dalam rangka saling menghargai/ menghormati sekaligus memperkaya budaya masing-masing.

Masyarakat multikultur merupakan masyarakat yang mampu memerankan dirinya sebagai arbiter, penengah bagj proses rekonsiliasi ketika proses dialektika tersebut menemui kejumudan/titik jenuh. Untuk keperluan ini masyarakat dituntut untuk meningkatkan kecerdasan intelektual, emosional, dan spiritual agar dapat memiliki sensitifitas, sensibilitas, apresiasi, simpati dan empati terhadap outsider. Pendapat 
pakar lainnya, ${ }^{5}$ masyarakat multikultur menyimpan banyak kekuatan dari masing-masing kelompok, sekaligus menjadi benih perpecahan. Apabila pertimbangan-pertimbangan emosional yang dipentingkan, maka akan lahir pendapat-pendapat fundamentalis atau yang mementingkan kepentingan kelompok sendiri dan menganggap kelompok-kelompok lain sebagai musuh. Tetapi apabila analisis rasio yang jernih digunakan dalam memilah-milah kekuatan yang dimiliki oleh suatu kelompok budaya atau kapital budaya, kekuatan sosial (social capital), dan kekuatan intelektual dari suatu komunitas, maka diyakini multikultur menyimpan cukup energi untuk menggerakkan masyarakat dalam skala yang berdampak luas dalam sendi-sendi kehidupan manusia itu sendiri.

Multikulturalisme sebenarnya merupakan konsep dimana sebuah komunitas dalam konteks kebangsaan dapat mengakui keberagaman, perbedaan dan kemajemukan budaya, baik ras, suku (etnis), dan agama. Sebuah konsep yang memberikan pemahaman bahwa sebuah bangsa yang plural atau majemuk adalah bangsa yang dipenuhi dengan budaya-budaya yang beragam. Bangsa yang multikultur adalah bangsa yang kelompokkelompok etnik atau budaya (etnic and cultural groups) yang ada dapat hidup berdampingan secara damai dalam prinsip co existence yang ditandai oleh kesediaan untuk menghormati budaya lain.

Secara umum, multikulturalisme dalam karakteristik sosial digunakan dalam rangka berjalannya interaksi sosial dalam masyarakat. Interaksi sosial merupakan kunci dari semua kehidupan sosial. Tanpa interaksi sosial, tidak mungkin ada kehidupan bersama. Interaksi sosial selalu didahului oleh suatu kontak sosial dan komunikasi. Terjadinya interaksi sosial dapat dipengaruhi oleh adanya jarak sosial dari pelaku interaksi itu sendiri. Proses interaksi sosial dimulai dengan kontak atau komunikasi sosial. Kontak ini dilanjutkan dengan proses-proses yang asosiatif (associative prosseses) ataupun disosiatif atau oposisional (dissociative processes). Proses-proses asosiatif dimulai dengan kerjasama (cooperation) dan dilanjutkan dengan akomodasi (accomodation), asimilasi (assimilation), dan akulturasi (acculturation). Adapun disosiasi dimulai dari persaingan (competition), kontravensi (contravention), antara kompetisi dan konflik, dan konflik. Interaksi sosial dalam multikultur

\footnotetext{
${ }^{5}$ Tilaar, H.A.R, Pendidikan Kebudayaan, dan Masyarakat Madani Indonesia: Strategi Reformasi Pendidikan Nastonal, (Bandung: Remaja Rossda-karya, 2004 ) h. 37
} 
memerlukan pengenalan dan pemahaman atas karakteristik sosial yang menjadi ciri khas komunitasnya.

\section{Memahami Pendidikan Multikultural}

Berdasarkan kondisi masyarakat Indonesia yang multikultural, maka untuk membentuk negara Indonesia yang kokoh perlu mengembangkan jenis pendidikan yang cocok untuk bangsa yang multikultural. Jenis pendidikan yang cocok untuk bangsa yang multikultur ini adalah Pendidikan Multikultural.

Pendidikan Multikultural paling tidak menyangkut tiga hal yaitu (1) ide dan kesadaran akan nilai pentingnya keragaman budaya, (2) gerakan pembaharuan pendidikan dan (3) proses.

Pendidikan Multikultural berkaitan dengan ide, bahwa semua siswa tanpa memandang karakteristik budayanya itu seharusnya memiliki kesempatan yang sama untuk belajar di sekolah. Perbedaan yang ada itu merupakan keniscayaan atau kepastian adanya namun perbedaan itu harus diterima secara wajar dan bukan untuk membedakan. Artinya perbedaan itu perlu kita terima sebagai suatu kewajaran dan perlu sikap toleransi agar kita bisa hidup berdampingan secara damai tanpa melihat unsur yang berbeda itu untuk membeda-bedakan.

Pendidikan Multikultural ini memberikan pemahaman mengenai berbagai jenis kegiatan pendidikan sebagai bagian integral dari kebudayaan universal. Di dalamnya akan dibahas kebudayaan yang teraktualisasi secara internasional, regional, dan lokal sepanjang sejarah kemanusiaan. Kegiatan pendidikan sebagai interaksi sosio-kultural paedagogis di Indonesia bukan hanya dilakukan oleh suku bangsa Indonesia, tapi berbagai bangsa. Di dalam Pendidikan Multikultural ini akan diungkap pula aktivitas paedagogis masa lalu, masa kini dan masa depan di berbagai belahan dunia dengan fokus kebudayaan Indonesia.

Ide penting yang lain dalam Pendidikan Multikultural adalah bahwa sebagian siswa karena karakteristik tersebut di atas, ternyata ada yang memiliki kesempatan yang lebih baik untuk belajar di sekolah favorit tertentu sedangkan siswa dengan karakteristik budaya yang berbeda tidak memiliki kesempatan itu.

Beberapa karakteristik institusional dari sekolah secara sistematis menolak kelompok siswa untuk mendapatkan kesempatan pendidikan yang sama, walaupun itu dilakukan secara halus. Dalam arti, dibungkus dalam bentuk aturan yang hanya bisa dipenuhi oleh segolongan tertentu 
dan tidak bisa dipenuhi oleh golongan yang lain. Kita perhatikan di lingkungan sekitar kita. Ada kesenjangan ketika muncul fenomena sekolah favorit yang didominasi oleh golongan orang kaya karena ada kebijakan lembaga yang mengharuskan untuk membayar uang pangkal yang mahal untuk bisa masuk dalam kelompok sekolah favorit itu. Ada kebijakan yang dipandang tidak adil bagi golongan Tionghoa karena ada diskriminasi terhadap kelompok mereka sehingga mereka hanya berkecimpung di bidang yang sangat terbatas, misalnya dagang, pengacara, dokter dan mengalami kesulitan berkarier di bidang ketentaraan dan pemerintahan. Mereka dan sebagian warga negara asing lainnya sulit mendapatkan status kewarganegaraan bagi anak-anak mereka sebelum tahun 2006.

Pendidikan Multikultural bisa muncul berbentuk bidang studi, program, dan praktek yang direncanakan lembaga pendidikan untuk merespon tuntutan, kebutuhan dan aspirasi berbagai kelompok.

Pendidikan Multikultural juga merupakan proses (pendidikan) yang tujuannya tidak akan pernah terrealisasikan secara penuh. Pendidikan multikultural adalah proses "menjadi". Pendidikan multikultural harus dipandang sebagai suatu proses yang terus-menerus dan bukan sebagai sesuatu yang langsung bisa tercapai. Tujuan utama dari pendidikan multikultural adalah untuk memperbaiki prestasi secara utuh bukan sekedar meningkatkan skor.

Persamaan pendidikan, seperti juga kebebasan dan keadilan, merupakan ide umat manusia yang harus dicapai dengan perjuangan keras namun tidak pernah dapat mencapainya secara penuh. Ras, gender, dan diskriminasi terhadap orang yang berkebutuhan akan tetap ada sekalipun kita telah berusaha sekeras mungkin menghilangkan masalah ini. Jika prasangka dan diskriminasi dikurangi pada suatu kelompok, biasanya keduanya terarah pada kelompok lain atau mengambil bentuk yang lain. Karena tujuan Pendidikan Multikultur tidak akan pernah tercapai secara penuh, kita seharusnya bekerja secara kontinyu meningkatkan persamaan pendidikan untuk semua siswa (educational equality for all students).

Seperti halnya dalam suatu dialog pendidikan, individu cenderung mengubah konsep untuk disesuaikan dengan fokus tertentu. Beberapa di antaranya membahas pendidikan multikultural sebagai suatu perubahan kurikulum, mungkin dengan menambah materi dan perspektif baru. Yang lain berbicara tentang isu iklim kelas dan gaya mengajar yang dipergunakan kelompok tertentu. Yang lain berfokus pada isu sistem dan kelembagaan seperti jurusan, tes baku, atau ketidak cocokan pendanaan antara golongan tertentu yang mendapat jatah lebih sementara yang lain 
kurang mendapat perhatian. Yang lain lagi melihat perubahan pendidikan sebagai bagian dari perubahan masyarakat yang lebih besar di mana kita mengeksplorasi dan mengkritik dasar-dasar kemasyarakatan yang menindas dan bagaimana pendidikan berfungsi untuk memelihara status quo seperti di Amerika Serikat yang terlalu berpihak pada supremasi kulit putih, kapitalisme, situasi sosio-ekonomi global dan eksploitasi. Sekalipun banyak perbedaan konsep pendidikan multikultural, ada sejumlah ide yang dimiliki bersama dari semua pemikiran dan merupakan dasar bagi pemahaman pendidikan multikultural: (1) kesempatan yang sama bagi setiap siswa untuk mewujudkan potensi sepenuhnya; (2) penyiapan pelajar untuk berpartisipasi penuh dalam masyarakat antar budaya; (3) penyiapan pengajar agar memudahkan belajar bagi setiap siswa secara efektif, tanpa memperhatikan perbedaan atau persamaan budaya dengan dirinya; (4) partisipasi aktif sekolah dalam menghilangkan penindasan dalam segala bentuknya; (5) pendidikan yang berpusat pada siswa dengan mendengarkan aspirasi dan pengalaman siswa, pendidik, aktivis, dan yang lain harus mengambil peranan lebih aktif dalam mengkaji kembali semua praktek pendidikan, termasuk teori belajar, pendekatan mengajar, evaluasi, psikhologi sekolah dan bimbingan, materi pendidikan dan buku teks, dan lain-lain.

Menurut Gorski, pendidikan multikultural merupakan pendekatan progresif untuk mengubah pendidikan secara holistik dengan mengkritik dan memusatkan perhatian pada kelemahan, kegagalan, dan praktek diskriminatif di dalam pendidikan. Keadilan sosial, persamaan pendidikan, dan dedikasi menjadi landasan pendidikan multikultural dalam memfasilitasi pengalaman pendidikan agar semua siswa dapat mewujudkan semua potensinya secara penuh dan menjadikannya sebagai manusia yang sadar dan aktif secara lokal, nasional, dan global. ${ }^{6}$

Paparan di atas sekaligus mengisyaratkan, perlunya upaya membangun pendidikan multikultural. Pendidikan multikultural dapat menjadi elemen yang kuat dalam kurikulum Indonesia untuk mengembangkan kompetensi dan ketrampilan hidup (life skills). Masyarakat Indonesia terdiri dari masyarakat multikultur yang mencakup berbagai macam perspektif budaya yang berbeda. Jadi sangat relevan bagi sekolah di Indonesia untuk menerapkan pendidikan multikultural. Pendidikan Multikultural dapat melatih siswa untuk menghormati dan

${ }^{6}$ Gorski. Educating Citizens for Democracy, (London: Oxford University Press, 2001). 
toleransi terhadap semua kebudayaan. Pendidikan multikultural sebagai kesadaran merupakan suatu pendekatan yang didasarkan pada keyakinan bahwa budaya merupakan salah satu kekuatan yang dapat menjelaskan perilaku manusia. Budaya memiliki peranan yang sangat besar di dalam menentukan arah kerjasama maupun konflik antar sesama manusia.

Atas dasar pemikiran ini, maka sudah saatnya pendidikan multikultural di Indonesia dirumuskan melalui pencarian nilai-nilai inti untuk pendidikan multikultural. Menurut Bennett dalam Tilaar orientasi nilai-nilai inti (core value) pada pendidikan multikultur antara lain: (1) Apresiasi terhadap adanya kenyataan pluralitas budaya dalam masyarakat; (2) Pengakuan terhadap harkat dan martabat dan hak asasi manusia; (3) Pengembangan tanggung jawab masyarakat dunia; dan (4) Pengembangan tanggung jawab menusia terhadap planet bumi. $^{7}$

Core value pendidikan multikultur mengingatkan pada sirkulerisme pendidikan multikultur. Sirkulerisme pendidikan multikultur, dapat mencakup empat hubungan dimensi; dimensi manusia dengan Allah, manusia dengan manusia, manusia dengan alam semesta, dan manusia dengan dirinya sendiri. Dengan demikian, core value pada pendidikan multikultur mencapai totalitas hubungan yang menjadi titik pusat perhatian. Totalitas hubungan sesuai dengan derajat nilai-nilai diri, kemanusiaan, dan kealaman.

Perumusan core value ini sangat penting untuk membangun tujuan pendidikan multikultur. Menurut Bennett dalam Tilaar nilai-nilai inti (core value) yang rnengarah pada tujuan pendidikan multikultur antara lain:

1) Mengembangkan perspektif sejarah (ethnohistorisitas) yang beragam dari kelompok-kelompok masyarakat,

2) Memperkuat kesadaran budaya hidup di masyarakat,

3) Menerima dan menghargai perbedaan dalam keberagaman,

4) Memperkuat kompetensi interkultural dari budaya-budaya yang hidup di masyarakat,

5) Membasmi rasisme, seksisme, dan berbagai jenis prasangka (prejudice),

6) Mengembangkan kesadaran atas kepemilikan planet bumi dan mengembangkan keterampilan aksi sosial (social action). ${ }^{8}$

\footnotetext{
${ }^{7}$ Tilaar, H.A.R, Pendidikan Kebudayaan, dan Masyarakat Madani Indonesia: Strategi Reformasi Pendidikan Nastonal, (Bandung: Remaja Rossda-karya, 2004 ), h. 171

${ }^{8}$ Ibid, 171-172
} 


\section{E. Pemahaman Pendidikan Multiagama}

Memahami dan mengaplikasikan ajaran Islam dalam kehidupan masyarakat harus dilakukan secara komprehensif dalam masyarakat Muslim. Di samping itu, Islam dapat juga diaplikasikan dalam masyarakat manapun, sebab secara esensial ia merupakan nilai yang bersifat universal. Kendatipun dapat dipahami bahwa Islam yang hakiki hanya dirujukkan kepada konsep Al-quran, tetapi dampak sosialnya dapat dirasakan oleh manusia secara keseluruhan di muka bumi ini.

Dalam kehidupan antar bangsa, nilai-nilai ajaran Islam menjadi sangat relevan untuk dilaksanakan guna menyatukan umat manusia dalam suatu kesatuan kebenaran dan keadilan. Dominasi salah satu etnis atau negara merupakan pengingkaran terhadap makna Islam, sebab ia hanya setia pada nilai kebenaran dan keadilan yang bersifat universal. Dari segi agama, ajaran Islam menunjukkan universalisme dengan doktrin monoteisme dan prinsip kesatuan alamnya.

Ditinjau dari segi sosiologi, universalisme Islam ditampakkan bahwa wahyu ditujukan kepada semua manusia agar mereka menganut agama islam, dan dalam tingkat yang lain ditujukan kepada umat Islam secara khusus untuk menunjukan peraturan-peraturan yang harus mereka ikuti. Karena itu maka pembentukan masyarakat yang terpisah merupakan suatu akibat wajar dari ajaran Al-Qur'an tanpa mengurangi universalisme Islam.

Hubungan antara muslim dengan penganut agama lain tidak dilarang oleh syariat Islam, kecuali bekerja sama dalam persoalan aqidah dan ibadah. Kedua persoalan tersebut merupakan hak intern umat Islam yang tidak boleh dicamputi pihak lain, tetapi aspek sosial kemasyarakatan dapat bersatu dalam kerja samayang baik. Kerja sama antar umat bergama merupakan bagian dari hubungan sosial anatar manusia yang tidak dilarang dalam ajaran Islam. Hubungan dan kerja sama dalam bidangbidang ekonomi, politik, maupun budaya tidak dilarang, bahkan dianjurkan sepanjang berada dalam ruang lingkup kebaikan.

\section{F. Memahami Konflik Multiagama di Aceh}

Hasil studi lapangan yang dilakukan penulis di Aceh Singkil dengan melakukan beberapa wawancara kepada masyarakat di Aceh Singkil terkait kronologis awal kerusuhan antar umat beragama di kabupaten tersebut, ternyata konflik antar umat beragama sudah berlangsung 36 tahun yang lalu, tepatnya sejak tahun 1979. Salah seorang 
penduduk Aceh Singkil, Muklish (60 tahun), menguraikan secara detail kronologis kejadian awal konflik di Kabupaten Aceh Singkil, mulai dari tahun 1979 hingga bentrokan yang terjadi pada Selasa, 13 Oktober 2015.

Pada 11 Juli 1979 di Lipat Kajang, sebuah perjanjian yang ditandatangani secara bersama-sama oleh 8 ulama perwakilan umat Islam dan 8 pengurus gereja/perwakilan umat Kristen. Terbentuk satu kesepakatan untuk tidak melaksanakan ataupun membangun kembali (rehab) gereja sebelum mendapat izin dari Pemerintah Daerah Tingkat II. Selanjutnya 13 Oktober 1979 dibuatlah ikrar untuk menjaga kerukunan antar umat beragama dan menaati perjanjian yang telah dibuat $11 \mathrm{Juli}$ 1979.

Penduduk Aceh Singkil lainnya yaitu Bariah (58 tahun) mengungkapkan bahwa telah dibuat ikrar yang ditandatangani 11 Pemuka Agama Islam dan 11 Pemuka Agama Kristen disaksikan dan ditandatangi oleh Muspida Kabupaten Aceh Selatan (saat itu belum menjadi Aceh Singkil), Kabupaten Dairi-Sumut, Kabupaten Tapteng-Sumut, juga disaksikan oleh unsur Muspika Kecamatan Simpang Kanan. Tanggal 11 Oktober 2001 kembali dibuat surat perjanjian, setelah sebelumnya, salah satu gereja di Kecamatan Suro dibakar. Pembakaran ini diduga karena melanggar aturan yang telah dibuat sebelumnya, yakni pendirian gereja tanpa izin.

Kemudian dibuatlah ruang dialog dalam sebuah pertemuan yang difasilitasi muspida. Hasil dialog tersebut adalah sebagai berikut: Gereja di Aceh Singkil hanya boleh satu unit, yaitu Gereja Kuta Kerangan dengan ukuran $12 \times 24$ meter dan tidak bertingkat. Undung-undung (rumah ibadah berukuran kecil, red) hanya boleh 4, yaitu: 1 gereja di Desa Keras Kecamatan Suro, 1 gereja di Desa Napagaluh Kecamatan Danau Paris, dan 1 gereja di Desa Suka Marmur Kecamatan Gunung Meriah, dan 1 gereja lagi di Desa Lae Gecih Kecamatan Simpang Kanan.

Apabila terdapat gereja atau undung-undung selain tersebut di atas, harus dibongkar oleh umat Kristen itu sendiri. Dalam hal ini, umat Kristen harus menepati janji dan mentaati hukum, aturan dan perjanjian yang telah disepakati. Kenyataannya, bukannya dibongkar, tapi malah memperbanyak bangunan gereja baru dan direhab. Menurut catatan Forum Umat Islam Aceh Singkil, saat ini sudah 27 unit gereja yang telah berdiri di Aceh Singkil.

"Kenapa umat Islam takut bersuara. Apakah kita harus menggadaikan akidah kita demi alasan klasik tidak toleran," ujar tokoh masyarakat 
Muslim Aceh Singkil, Hambalisyah Sinaga, yang merupakan juga salah seorang narasumber dalam penelitian ini.

Tanggal 30 April 2012 umat Islam di Kabupaten Aceh Singkil turun aksi ke jalan untuk menyampaikan protesnya ke kantor Bupati Kabupaten Singkil terkait maraknya bangunan gereja liar di Kabupaten Aceh Singkil sebanyak 27 unit yang tersebar di 7 kecamatan. Pada 1 Mei 2012 Tim Penertiban yang dibentuk oleh Pemda Aceh Singkil turun ke lokasi untuk menyegel 5 unit gereja, namun kenyataannya esok harinya (2 Mei 2012) tim penertiban itu tidak jadi turun ke lokasi, karena ada acara Hardiknas. Pada tanggal 3 Mei 2012, Tim Penertiban kembali turun ke lapangan dan berhasil menyegel 13 gereja. Lima hari kemudian (8 Mei 2012) Tim Penertiban kembali turun ke lapangan dan berhasil menyegel 2 gereja.

Pertanyaan yang muncul kemudian adalah, benarkah masyarakat Aceh tidak memiliki toleransi dalam menjalankan ibadah agama? Lantas, apakah pembakaran tempat ibadah dalam insiden Aceh Singkil itu sudah cukup kuat sebagai alat justifikasi adanya kebencian masyarakat Aceh pada agama tertentu di luar pemeluk agama mayoritas?

Bagi orang yang paham dengan sejarah Aceh dan dinamika geopolitik di Aceh, pasti akan bersikap sangat berhati-hati dalam membaca konflik di Aceh Singkil. Sebab, di Aceh Singkil juga telah terbentuk komunitas multikultur dengan cara pandang dan cara berpikir yang sangat variatif. Adanya persaingan antar etnis dan suku yang tidak sehat akan memunculkan problema konflik yang setipa saat akan terjadi dan bias saja berulang terus menerus tanpa diketahui batas akhirnya. Untuk itu sangat dibutuhkan cara pandang dan cara pikir yang maju bagi suku-suku dan juga etnis-etnis yang tinggal menetap maupun yang tinggal sementara di Aceh Singkil. Sesungguhnya konflik itu akan menimbulkan kerusakan di sana-sini, sedangkan kedamaian itu akan memberikan kenyamanan dan ketentraman hidup.

Pendek kata, walau dalam insiden Aceh Singkil terdapat pembakaran tempat ibadah, bukan berarti ada intoleransi yang tumbuh subur di Aceh. Tak aneh, jika Amir Faisal (salah satu putra Aceh di Jakarta) meminta kepada semua pihak agar tidak buru-buru menyudutkan umat Islam terkait adanya pembakaran tempat ibadah di Aceh Singkil. Pernyataan Amir Faisal itu diperkuat oleh Puluhan Organisasi Islam Aceh Singkil yang tergabung dalam Forum Umat Islam (FUI) Aceh Singkil. Terkait peristiwa pembakaran tempat ibadah di Singkil, FUI mengeluarkan 
pernyataan sikap berisi 11 poin. Salah satunya, mengimbau kepada semua pihak di luar Aceh Singkil jangan membuat pernyataan menyesatkan yang menyudutkan umat Muslim Aceh Singkil yang tidak mengetahui akar permasalahan sebenarnya.

Salah seorang tokoh masyarakat Muslim lainnya di Aceh Singkil, Abd Walid, 65 tahun, menambahkan bahwa sebenarnya faktor kemiskinan dan juga kesenjangan ekonomi dan hukum yang tidak konsisten menyebabkan terjadinya konflik ini. Dia juga menambahkan bahwa masyarakat Aceh Singkil sebenarnya ingin hidup damai, tenteram dalam mencari nafkah dengan baik, namun karena memang ini tidak bisa ditolerir lagi makanya kerusuhan tersebut terjadi.

\section{G. Memahami Konflik Multikultural di Aceh Singkil}

Konflik di Aceh Singkil harusnya tidak boleh dibaca secara parsial dengan perspektif yang amat dangkal. Setidaknya, konflik di Aceh Singkil jangan dilihat secara sempit hanya dengan dasar adanya pembakaran tempat ibadah. Kalau dilihat dari sisi budaya misalnya, masyarakat Aceh sebenarnya terbilang cukup terbuka dan bisa menerima adanya multikulturalisme. Faktanya, mereka dapat hidup rukun dalam keberagaman suku, ras maupun agama. Bahkan, secara historis, multikulturalisme di Aceh telah dipraktikkan sejak lama tentang kerukunan umat beragama tersebut bahkan sejak era kesultanan Aceh prakolonial.

Seorang tokoh masyarakat Aceh Singkil lainnya yang sangat berpengaruh (Muhammad Mukhlis, 62 tahun) menyampaikan kegeramannya dan juga kegundahannya atas terjadinya konflik yang berbau SARA ini. Dia sangat tidak setuju kalau konflik ini dikaitkan hanya dengan agama. Dia berpendapat kalau ini merupakan konflik cultural juga. Dia cenderung mengatakan bahwa ini merupakan proses pendewasaan dalam kehidupan berbangsa dan bernegara. Namun demikian memang perlu adanya pendewasaan dalam berinteraksi antara sesama manusia yang hidup dalam satu wilayah yang kental akan nuansa kulturnya. Proses pendewasaan inilah yang terus menerus mengalami pasang surut karena berbagai faktor kehidupan yang semakin hari semakin berat. Dia juga menjelaskan, masa kesultanan misalnya, masyarakat Aceh sudah bisa menerima kehadiran orang India, etnis Melayu, dan etnis Tionghoa. Tidak hanya itu, sampai permaisuri kesultanan Aceh berasal dari etnis non-Aceh, seperti Putroe Phang (dari negeri Pahang Malaysia). Fakta adanya multikulturalisme di Aceh makin jelas di masa kini, antara 
lain adanya sekolah non-muslim di Banda Aceh (seperti Perguruan Kristen Methodist dan Perguruan Katolik Budi Darma). Ada juga perkampungan etnis Tionghoa (pecinan) di kawasan Peunayong Banda Aceh, perkampungan Keling (India keturunan) di Kabupaten Pidie dan gampong Jawa di kota Banda Aceh. Dari fakta di atas terlihat bahwa masyarakat Aceh adalah masyarakat multikultural yang tersusun dari keanekaragaman etnis, budaya, bahasa dan agama. Hal ini menunjukkan bahwa Aceh bukanlah milik etnis Aceh saja, tetapi milik semua etnis yang mendiami wilayah Aceh tanpa terkecuali.

Salah seorang tokoh pemuda Muslim di Aceh Singkil (Abubakar, 51 tahun) juga menyampaikan hal senada bahwa konflik di Aceh Singkil bukan hanya merupakan konflik agama tapi juga konflik budaya karena memang selama ini toleransi beragama itu sudah dibangun dan tebangun sejak lama. Namun karena adanya perbindahan suku tertentu ke daerah Aceh Singkil yang memiliki budaya yang berbeda dengan karekter berbeda dan cara pandang yang berbeda pula dalam melakukan aktifitas sehari-hari, inilah yang menyebabkan konflik budaya itu muncul.

Dia samping itu Menteri Agama Lukman Hakim Syaifuddin juga telah mengatakan, insiden berdarah di Aceh Singkil itu tak sepenuhnya masalah agama. Bahkan, Menteri Agama justru mensinyalir, kemungkinan adanya sesuatu kepentingan lain di balik terjadinya insiden Aceh Singkil tersebut. Sayangnya, Menteri Agama tidak mengungkapan sinyalemen itu secara lengkap. Sementara Wakil Ketua Komnas HAM, Anshori Sinungan, menduga adanya keterlibatan orang-orang luar di balik pembakaran tempat ibadah di Aceh Singkil. Sedang tujuannya kemungkinan untuk membuat gaduh bangsa Indonesia supaya menjadi lemah.

Dari berbagai wawancara yang dilakukan, ternyata ada informasi tambahan yang diperoleh dari masyarakat setempat yang mengeluhkan tentang kemiskinan yang bertahun-tahun yang merupakan juga faktor pendorong terjadinya konflik di Aceh. Ketimpangan ekonomi antara penduduk asli dengan pendatang terlihat begitu jelas.

Seorang pedagang di Aceh Singkil (Idu Sa'diah, 48 tahun) mengungkapkan bahwa kemiskinan yang terjadi bertahun-tahun di Aceh Singkil juga merupakan faktor penyebab terjadinya konflik meskipun faktor tersebut bukan dominan. Dia menambahkan bahwa seolah-olah kemiskinan sudah menjadi budaya yang pahit yang harus dijalani oleh masyarakat di sana. Ketimpangan ekonomi yang tajam di tanah yang 
begitu subur dengan sumber daya alam yang melimpah bisa saja juga menjadi bagian dari munculnya konflik yang selama ini terjadi.

Seorang pedagang lainnya (Nurlela, 37 tahun) juga mengamini apa yang disebutkan temannya tadi (Nurlela, 37 tahun). Dia merasakan begitu sulitnya untuk mengumpulkan rupiah demi rupiah guna memenuhi kebutuhannya sehari-hari. Dia juga tidak manampik bahwa kerusuhan yang telah terjadi bisa saja akibat sulitnya mencari nafkah, sehingga orang buat kerusuhan di sana-sini.

Sulitnya perekonomian dan sulitnya lapangan pekerjaan telah menjadi komoditi politik bagi individu-individu maupun kelompak tertentu guna merusak stabilitas keamanan yang selama ini sudah terjalin. Banyak pihak yang tidak senang melihat kerukunan hidup terjalin begitu lama di Aceh Singkil. Oleh karena itu, semua pihak harus benar-benar bisa berpikir jernih agar kinflik seperti ini tidak terulang kembali.

\section{H. Kesimpulan}

Setelah dilakukan penelitian yang mendalam dan komprehensif atas terjadinya konflik di Aceh Singkil, maka dapat disimpulkan bahwa: ada beberapa kemungkinan munculya konflik tersebut:

1. Pemahaman agama yang begitu rendah, baik itu dari penduduk yang sudah lama tinggal di Aceh Singkil maupun penduduk pendatang, telah mengakibatkan terjadinya kerusahan ini.

2. Pemahaman multikultural yang begitu rendah pada masyarakat Aceh Singkil telah mengakibatkan terjadinya kerusuhan yang mengakibatkan kerusakan di sana sini. Hal ini juga telah menyebabkan ketidakstabilan dalam melakukan aktifitas kehidupan sehari-hari di Aceh Singkil. Multikultural yang terbentuk di Aceh Singkil memiliki kelemahan dan sekaligus kekuatan. Apabila cara pandang masyarakat Aceh Singkil terhadap keberagaman budaya tidak disikapi sebagai rahmatan lil'alamin, maka multikultur yang telah tertanam di Aceh Singkil bisa saja menjadi bara api yang senantiasa akan membakar dan menyala-nyala di bumi masyarakat Aceh Singkil. Namun apabila itu dipandang sebagai keberagaman khasanah budaya, maka dia akan memberikan warna warni budaya yang indah yang ada di Aceh Singkil.

3. Di samping masalah multiagama dan multikultural, konflik di Aceh Singkil juga disebabkan oleh kesenjangan ekonomi yang telah terjadi bertahun-tahun. 


\section{DAFTAR PUSTAKA}

Assegaf, R.A., 2004, Pendidikan Tanpa Kekerasan: Tipologi Kondisi, Kasus, dan Konsep, Jogjakarta: Tiara Wacana, Cetakan Pertama.

Banks, J.A. (1994) An Introduction to multicultural education, Boston: Allyn and Bacon.

Dawam, Ainurrofiq., 2003, Emoh Sekolah: Menolak "Komersialisasi Pendidikan dan Kanibalisme Intelektual", Jogjakarta: Jnspeal Ahimsakarya Press, Cetakan Pertama.

Dewey, J., 1953, How We Think, boston: D.C.Heath.

Gorski. 2001. Educating Citizens for Democracy, London: Oxford University Press.

Husniyatus Salamah Z,.2013, "Pendidikan Multikultural: Upaya Membangun Keberagaman Inklusif di Sekolah".

Kalidjernih, F.K., 2008. Cakrawala Pendidikan Kewarganegaraan. Bandung: Grasindo.

Khoironi., 2004, Pendidikan Profetik, Jogjakarta: Pustaka Pelajar, Cetakan Pertama.

Milner, H., 2002, Civic Literacy: How Informed Citizens Makes Democracy Work, Hanover: University Press of New England

Nasikun. 2007. Sistem Politik Indonesia.Yogyakarta: Pustaka pelajar.

Tilaar, H.A.R, 2000, Pendidikan Kebudayaan, dan Masyarakat Madani Indonesia: Strategi Reformasi Pendidikan Nastonal, Bandung: Remaja Rossda-karya, Cetakan Kedua

Tilaar, H.A.R, 2000, 2003 Multikulturalisme: Tantangan Global Masa Depan dalam Transformasi Pendidikan Nasional, Jakarta: Grasindo.

Wahid, Abdurahman., 2004, Keragaman Budaya Bangsa, Kompas, 23 Juni 2004.

Yaqin, Ainul., 2005, Pendidikan Multikultural: Cross-Culttiral Understanding untuk Demokrasi dan Keadilan, Yogjakarta: Pilar Media, Cetakan Pertama.

Zainal Abidin,. 2003, Sosiosophologi: Sosiologi Islam Berbasis Hikmah, Bandung: Pustaka Setia, Cetakan Pertama. 